\title{
Catalase Activity and Post-anoxic Injury in Monocotyledonous Species
}

\author{
LORNA S. MONK', R. BRAENDLE ${ }^{2}$ AND R. M. M. CRAWFORD \\ ${ }^{1}$ Department of Plant Biology and Ecology, The University, St. Andrews, \\ Fife KY16 9AL, Scotland, U.K. \\ ${ }^{2}$ Pflanzenphysiologisches Institut der Universitaet Bern, Switzerland
}

Received 10 September 1986

\begin{abstract}
Monk, L. S., Braendle, R. and Crawford, R. M. M. 1987. Catalase activity and post-anoxic injury in monocotyledonous species. -J. exp. Bot. 38: 233-246.

Three anoxia-intolerant species, Glyceria maxima, Juncus effusus and Iris germanica (var. Quechei), and three anoxia-tolerant species Schoenoplectus lacustris, Acorus calamus and Iris pseudacorus were chosen for investigation. Rhizomes of anoxia-intolerant species show increased catalase activities when returned to air after periods of prolonged anoxia. Levels of catalase remained fairly constant in anoxia-tolerant species under the same conditions. In the anoxia intolerant $G$. maxima, the postanoxic increase in catalase activity was reduced by circulating the anaerobic atmosphere. This treatment also reduced the ethanol content of the tissue under incubation, and increased the survival of the rhizomes as seen in their ability to resume growth in the post-anoxic phase. Exposure of anaerobic G. maxima rhizomes to ethanol vapour increased post-anoxic levels of catalase activity and when this produced a 5-fold increase always resulted in death of the rhizomes. Acetaldehyde vapour applied in the same way gave rise to increases in catalase activity followed by rapid death of the rhizomes.

It is suggested that post-anoxic oxidation of anaerobically accumulated ethanol may result in a surge of acetaldehyde production, which could exert a toxic effect on the recovering tissues. The possible role of catalase in an ethanol-oxidation reaction, which is well documented in anımals, is discussed in the light of the association between the natural accumulation of large concentrations of ethanol and subsequent post-anoxic death in some plant tissues.
\end{abstract}

Key words-Catalase, post-anoxia, ethanol.

Correspondence to: Department of Plant Btology and Ecology. The University, St. Andrews, Fife KYI6 9AL, Scotland, U.K.

\section{INTRODUCTION}

Catalase (E.C. 1.11.1.6) is localized in microbodies, and is characteristic of this subcellular organelle, which occurs ubiquitously in plants and animals. Microbody function may be very specific in certain plant tissues: photorespiratory reactions take place in the so-called peroxisomes of photosynthetic cells, and catabolism of lipids occurs in the glyoxysomes of fat-storing seeds. However, as yet no specific function has been ascribed to the microbodies occurring in root cells. Vigil (1973) has suggested that microbodies in general probably participate in several other aspects of cellular metabolism. These suggestions include generation and/or elimination of excessive reducing power, regulation of various metabolic pools by selective oxidation of uric acid, amino acids etc., synthesis of required amino acids 
for proteins or membrane lipids, and formation of carbon precursors essential for the synthesis of sucrose and other carbohydrates.

According to Oshino, Oshino, and Chance (1973) catalase, within the microbody of rat hepatocytes, can act in its 'catalatic' mode on hydrogen peroxide, and in additon in a 'peroxidatic' mode on ethanol. Regardless of the concentration of ethanol and the rate of hydrogen peroxide generation, a half-saturation of the steady-state of the catalasehydrogen peroxide intermediate indicated that $c .45 \%$ of the peroxide was utilized by the ethanol-oxidation reaction. In a review of metabolic pathways in peroxisomes and glyoxysomes, Tolbert (1981) noted that peroxisomal metabolism generally represents an alternative pathway, and in the case of ethanol metabolism may have significance at higher alcohol concentrations.

In a recent study on germinating castor bean, Donaldson, Soochan, and Zaras (1985) argued that ethanol accumulated during anaerobic stress could be oxidized by any of three separate systems, including one located in the endoplasmic reticulum and dependent on NADPH, and one which was confined to glyoxysome and dependent on a peroxideproducing substrate such as a fatty acid. The third alternative, alcohol dehydrogenase, requiring $\mathrm{NAD}$ for the oxidation of ethanol, was cited as the major reaction taking place. However, it is uncertain whether this could be the case in the light of studies such as that of Felder, Scandalios, and Liu (1973), where it was reported that, in maize, ADH is unable to oxidize ethanol in vitro at $\mathrm{pH} 6.0$. The reaction in the opposite direction i.e. from acetaldehyde to ethanol by contrast occurs readily at this $\mathrm{pH}$. Significant changes in $\mathrm{pH}$ during anaerobiosis have recently been shown in root tips of pea and maize, where cytoplasmic acidosis has been implicated in cell death (Roberts, Callis, Jardetzky, Walbot, and Freeling, 1984). In addition, it has been observed that catalase is able to oxidize formate peroxidatically to $\mathrm{CO}_{2}$ in spinach leaf extracts (in competition with formate dehydrogenase) over a wide range of $\mathrm{pH}$ values, and is significantly the predominant reaction at $\mathrm{pH} 5 \cdot 0$, since formate dehydrogenase has a pH optimum of 6.0-6.5 (Halliwell, 1974).

The present series of experiments was carried out on this background, to investigate the role of catalase in the recovery from prolonged anoxic stress in the rhizomatous storage organs of several monocotyledonous species. The species under study were selected for their known variation in their capacity to accumulate ethanol during anoxia (Monk, Crawford, and Braendle, 1984).

\section{MATERIALS AND METHODS}

Supplies of plants for experimentation were obtained from various sources. The relatively anoxiaintolerant Glyceria maxima (Hartm.) Holmberg and Juncus effusus L. were collected locally at Tentsmuir, Fife, while the third anoxia-sensitive species Iris germanica L. (var. Quechei) was provided by the University Botanic Garden. The related, but anoxia-tolerant Iris pseudacorus L. was collected from Dura Den, Fife; also tolerant, Schoenoplectus lacustris (L.) Palla was sent from Orkney and Acorus calamus $\mathrm{L}$. from Berne, Switzerland. All species were grown in a glasshouse for several months before harvesting for experiments. The plants were kept in a $16 \mathrm{~h} \mathrm{~d}^{-1}$ light regime at $293 \mathrm{~K}$, and since they were planted in coarse gravel only, were fed weekly with a modified Hoagland's solution (Epstein, 1972).

Before the experiment the rhizomes were surface-sterilized with $0.16 \mathrm{~mol} \mathrm{~m}^{-3}$ chloramphenicol. Anoxic incubation of rhizome material was accomplished by filling anaerobe jars (Gaspak, Becton Dickinson and Co., Cockeysville, U.S.A.), containing a palladium catalyst to remove traces of oxygen, in an anaerobic workbench (Forma Scientific, Ohio, U.S.A.), and subsequently placing them in incubators at $293 \mathrm{~K}$. The anoxic atmosphere thus consisted of $90 \%$ nitrogen and $10 \%$ hydrogen. The jars also contained methylene blue indicator strips which remain colourless in the absence of oxygen. During the post-anoxic phase in air rhizomes were kept on moist filter paper at $293 \mathrm{~K}$.

The high recovery rates found in all species preclude the possibility that peroxidases are interfering with the assay, producing an under-estimation of catalase activity. At the concentration of substrate 
used, peroxidase may react as rapidly as catalase $\left(10^{4} \mathrm{~m}^{3} \mathrm{~mol}^{-1} \mathrm{~s}^{-1}\right)$, and as argued for their case of glutathione peroxidase in animals the metabolic route of hydrogen peroxide will depend predominantly on the molarities of the enzymes competing (Flohé, Loschen, Guenzler, and Eichele, 1972). The good recovery rates also rule out the possibility that an endogenous inhibitor of catalase such as described by Sorenson and Scandalios (1976) in maize seedlings is in operation in any of the species tested.

The catalase activity of $1.0 \mathrm{~mm}$ thick transverse rhizome slices was estimated as rate of oxygen evolution in Sorensen's buffer ( $\mathrm{pH} 7.0)$ when hydrogen peroxide $\left(7.0 \mathrm{~mol} \mathrm{~m}^{-3}\right.$ final concentration) was added to the solution. An oxygen electrode (Rank Brothers, Bottisham, Cambridge) was used for these estimations. The buffer was always allowed to saturate with air at $298 \mathrm{~K}$ before rhizome slices were added, and the tissue allowed to respire, so that rate of oxygen evolution was taken between saturation point and zero.

Under these conditions catalase activity was proportional to the number of slices placed in the electrode and remained linear for approximately $30 \mathrm{~s}$. In additional experiments using rhizome slices ground in Sorensen's buffer and centrifuged for $5 \mathrm{~min}$ at $8730 \mathrm{~g}, 7.0 \mathrm{~mol} \mathrm{~m}^{-3}$ hydrogen peroxide gave a proportional response with the amount of extract added. Recovery experiments adding commercially purified bovine liver catalase (Boehringer, Mannheim) during the extraction of homogenized rhizome of $G$. maxima gave recovery rates of $87.3 \% \pm 4.9$ from aerobic tissue and $81.4 \% \pm 2.0$ in rhizomes from post-anoxic treatments. Rates of oxygen uptake and evolution were calculated from a chart recorder trace and expressed as nanomoles of oxygen evolved per minute per $\mathrm{cm}^{2}$ of rhizome tissue.

Recovery rates for catalase in the remaining five species for the two respective treatments were: $J$. effusus $85.3 \% \pm 3.6$ and $95.5 \% \pm 1.9 ;$ I. germanica $91.9 \% \pm 2.9$ and $83.9 \% \pm 4.1$; S. lacustris, $95.9 \% \pm 1.2$ and $94.3 \% \pm 2 \cdot 8 ;$ A. calamus $85 \cdot 5 \% \pm 1 \cdot 3$ and $89 \cdot 3 \% \pm 5 \cdot 5 ;$ I. pseudacorus, $85 \cdot 2 \% \pm 3 \cdot 4$ and $90.8 \% \pm 4 \cdot 6$. Due to the release of phenols on homogenization $3 \%$ polyvinyl-pyrrolidone-40 was added to the I. pseudacorus extracts to remove the complete inhibition of catalase activity.

For the studies on survival in anoxic closed versus open atmospheres, anaerobe jars with a volume of $2.4 \times 10^{-3} \mathrm{~m}^{3}$ provided the closed environment. An open atmosphere for rhizomes for the catalase assays was created by circulating the atmosphere in the anaerobic workbench (Crawford and Zochowski, 1984). In an alternative method the open anaerobic environment was created by passing over the rhizomes a constant flow of oxygen-free nitrogen $\left(45 \times 10^{-6} \mathrm{~m}^{3} \mathrm{~min}^{-1}\right)$. The nitrogen was prehumidified by bubbling through water and the rhizome were wrapped in moist filter paper to reduce the danger of desiccation. In this last case both closed and open treatments were placed in the growth cabinet in the dark at $293 \pm 3 \mathrm{~K}$. For experiments which involved the application of ethanol or acetaldehyde to the head space, $0.5 \times 10^{-6} \mathrm{~m}^{3}$ of a series of different concentrations of ethanol or acetaldehyde was placed in the anaerobe jars in turn, and allowed to equilibrate with the plant tissues over $3 \mathrm{~d}$ anoxia at $293 \mathrm{~K}$.

Ethanol and acetaldehyde evolved from rhizomes during anoxic and post-anoxic treatments were estimated in the head space over G. maxima rhizomes on a gas-liquid chromatograph. Head space samples were taken using an air-tight $1 \times 10^{-6} \mathrm{~m}^{3}$ gas syringe heated to $333 \mathrm{~K}$. The entire sample was then injected into a gas-liquid chromatography column $1.4 \mathrm{~m}$ long and $7.0 \mathrm{~mm}$ diameter filled with 100 mesh Porapak Q. The estimation was carried out isothermally $423 \mathrm{~K}$ with a gas flow of $40 \times 10^{-6} \mathrm{~m}^{-3}$ $\min ^{-1}$. Ethanol concentrations were calculated on the basis of peak area as measured with an integrating recorder (Hewlett-Packard-reporting integrator 3390). For the aerobic post-anoxic treatment, rhizomes were transferred to clean dry test tubes, $16 \times 10^{-6} \mathrm{~m}^{3}$ in volume and sealed with a Suba-Seal stopper. At intervals $0.5 \times 10^{-6} \mathrm{~m}^{3}$ aliquots of the head space gas were withdrawn by means of a gas syringe and injected into the G.L.C. for analysis. Ethanol accumulation in the tissue was measured by preparing an aqueous extract as already described in Crawford and Zochowski (1984) and gas -liquid chromatographic estimation was carried out as for the analysis of head space detailed above except for injection which used $1 \times 10^{-9} \mathrm{~m}^{3}$ liquid samples.

For the survival experiment, rhizomes with well-developed buds attached were washed, and green shoots and roots cut away. After surface-sterilization (as above) rhizomes were placed in the appropriate treatment in the growth cabinet in the dark at $293 \mathrm{~K}$. Rhizomes were planted out in the greenhouse in a mixture of peat and coarse gravel, and survival, i.e. regrowth of shoots and roots, was scored after 2 weeks.

\section{RESULTS}

Catalase activity was monitored during a 3-d aerobic recovery period in six species (three anoxia-tolerant-Fig. 1, three anoxia-intolerant-Fig. 2) where rhizomes had previously 


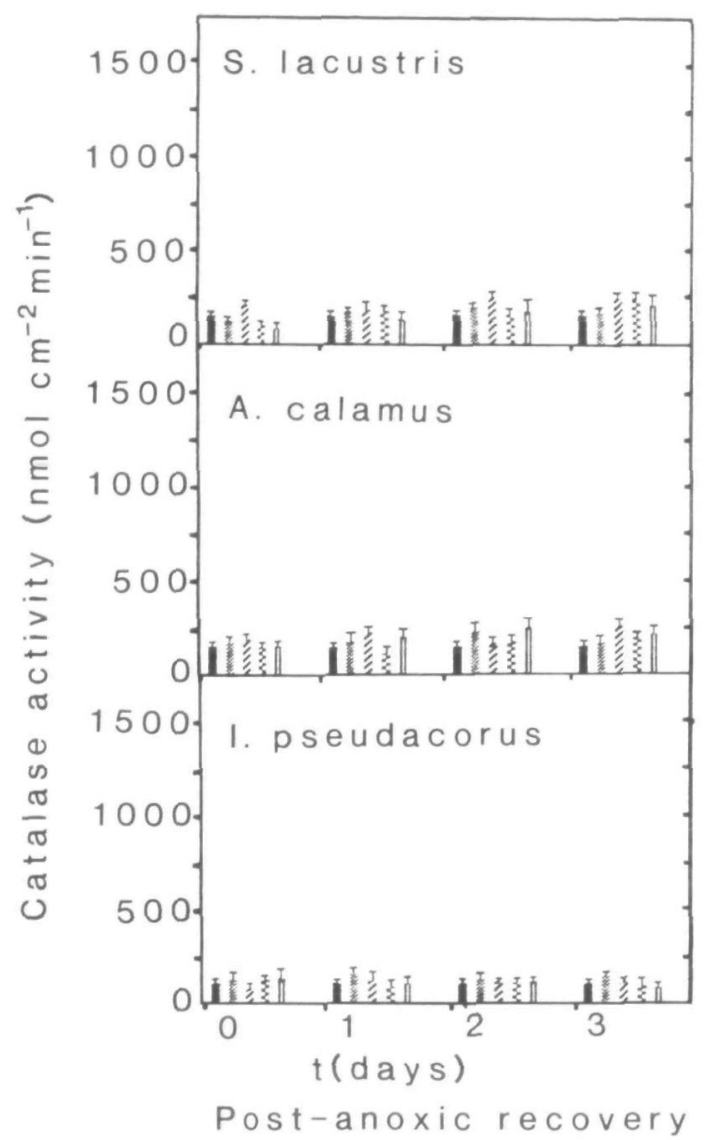

FIG. 1. The development of catalase activity on return to air in rhizomes of three anoxia-tolerant specres that were exposed to anoxia for up to $28 \mathrm{~d}$. The column sets represent $0-3 \mathrm{~d}$ post-anoxic treatment, and the different columns within the sets represent $0(\square), 7(*), 14(\xi), 21(\xi)$ and $28 \mathrm{~d}(\mathrm{II})$ previous anaerobic incubation $(n=3-6$, with standard error bars).

been subjected to 3, (two species only) 7, 14, 21 and $28 \mathrm{~d}$ of oxygen deprivation. Only very slight increases were found in the anoxia-tolerant species $S$. lacustris, $A$. calamus and $I$. pseudacorus, where amounts between $c .100-200 \mathrm{nmol} \mathrm{cm}^{-2} \mathrm{~min}^{-1}$ were measured. However, in the anoxia intolerant $J$. effusus (Barclay and Crawford, 1982) a 3- to 4-fold increase in activity, up to $1012 \mathrm{nmol} \mathrm{cm} \mathrm{cm}^{-2} \mathrm{~min}^{-1}$ was observed on return to air after 3-7 $\mathrm{d}$ oxygen deprivation. The longer periods of anoxia resulted in death of the tissue in this species before re-exposure to air. Similarly, in the relatively anoxia-intolerant 1 . germanica (Hetherington, Hunter, and Crawford, 1983) 2- to 3-fold increases in activity, up to $570 \mathrm{nmol} \mathrm{cm}^{-2} \mathrm{~min}^{-1}$ were observed during the post-anoxic period. Levels remained fairly constant during the absence of oxygen. On removal from the anaerobic incubator after $28 \mathrm{~d}$ anoxia rhizomes of Iris germanica exhibited low catalase activity which, after $24 \mathrm{~h}$, showed a drop to below control levels, indicating imminent death of the tissue.

The least anoxia-tolerant species investigated in this series of experiments was G. maxima (Fig. 2). After $7 \mathrm{~d}$ of anaerobiosis, catalase was found to be six times as active as at the beginning of the experiment. This level of catalase activity under anoxia was not exceeded in the longer periods of oxygen deprivation. Monitoring the 3-d post-anoxic phase in air, however, revealed a 12- to 19 -fold rise in the enzyme activity, up to $1651 \mathrm{nmol} \mathrm{cm}^{-2} \mathrm{~min}^{-1}$, 


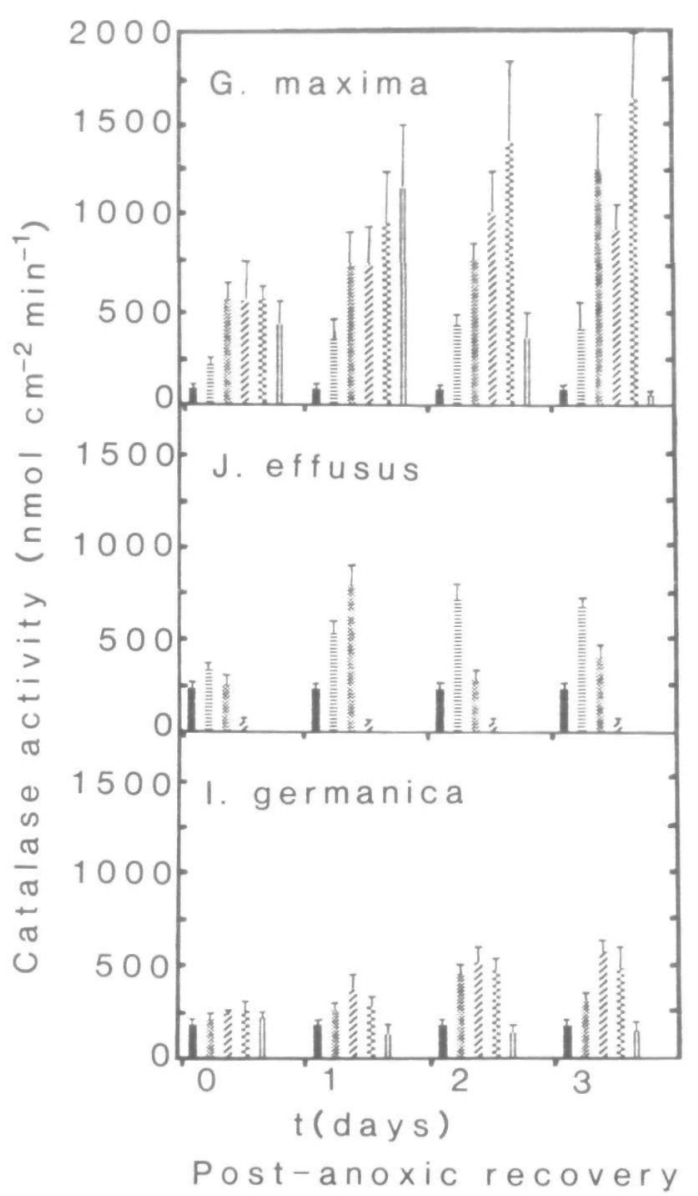

Fig. 2. The development of catalase activity on return to air in rhizomes of three anoxia-intolerant species that were exposed to anoxia for up to $28 \mathrm{~d}$. The column sets represent $0-3 \mathrm{~d}$ post-anoxic treatment, and the different columns within the sets represent $0(\boldsymbol{\sigma}), 3(\equiv)$-only two species, $7(\xi), 14(\zeta), 21$ (६) and $28 \mathrm{~d}$ (II) previous anaerobic incubation ( $n=3-6$, with standard error bars).

compared to initial levels. A 3-d anoxic treatment produced only a 2-fold increase in activity, with a further 2-fold increase on return to air.

Further experiments on the effects of altering the anaerobic environment on catalase activity were confined to $G$. maxima, the most responsive species. Circulation of the anaerobic environment over $5 \mathrm{~d}$ produced a significant reduction in catalase activity in the post-anoxic period (Fig. 3). During the course of the post-anoxic period in air, a level of catalase activity of $960 \mathrm{nmol} \mathrm{cm} \mathrm{cm}^{-2} \mathrm{~min}^{-1}$ (11-fold increase on initial levels) was found in rhizomes which had been in a closed anoxic environment, while a level of $352 \mathrm{nmol} \mathrm{cm}-2$ $\mathrm{min}^{-1}$ (only a 4-fold rise) was reached in the plants from the circulated anoxic treatment. The amounts of active catalase found in this latter treatment ( $5 \mathrm{~d}$ anoxia) are comparable to those in rhizomes that had been subjected to $3 \mathrm{~d}$ anaerobiosis under static conditions (Fig. 2).

The moving stream of nitrogen also removed considerable amounts of ethanol produced by alcoholic fermentation within the plants. Levels of ethanol in the rhizomes after $5 \mathrm{~d}$ anoxia in an open atmosphere were 6 -fold lower $\left(22.7 \mu \mathrm{mol} \mathrm{g}^{-1} \mathrm{fr}\right.$. wt. \pm 2.6 s.e. $)$ than levels found in rhizomes from the closed atmosphere $\left(134.7 \mu \mathrm{mol} \mathrm{g}^{-1}\right.$ fr. wt. $\pm 8 \cdot 1$ s.e. $)$. 


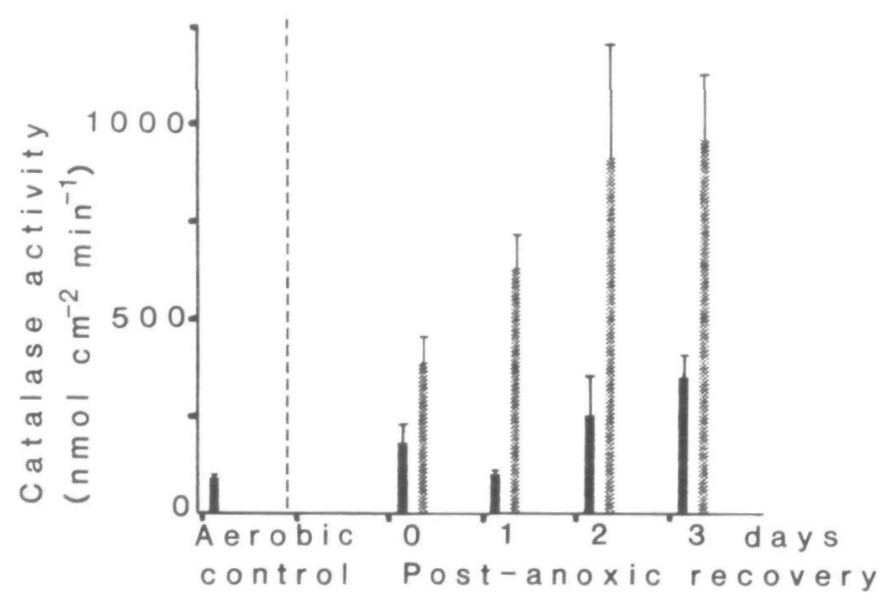

FIG. 3. Catalase activity in rhizomes of Glyceria maxima after $5 \mathrm{~d}$ in a static ( as opposed to a moving ( anaetobic atmosphere ( $n=3-6$, with standard error bars).

TABLE 1. The effect of a moving versus a static anaerobic environment on the survival probability $(P)$ of rhizomes of $\mathrm{G}$. maxima tested by growing-on for $14 d$ in air after the anaerobic treatment

$n=10$, two replicate experiments.

\begin{tabular}{llll}
\hline $\begin{array}{l}\text { Length of } \\
\text { treatment (d) }\end{array}$ & Static & Moving & Significance \\
\hline 3 & $P=1 \cdot 0$ & $1 \cdot 0$ & n.s. \\
4 & $P=\mathbf{0 . 7}$ & 0.8 & n.s. \\
5 & $P=\mathbf{0 . 3}$ & 0.8 & $<0.05$ \\
6 & $P=0.0$ & 0.1 & n.s. \\
\hline
\end{tabular}

Table 1 records the survival probabilities for rhizomes that have been anaerobically incubated in static and moving environments. Plants from both treatments showed $100 \%$ survival after 3-d oxygen deprivation. Four days without oxygen produced $20-30 \%$ mortalities in rhizomes from both conditions, while $5 \mathrm{~d}$ appeared to be critical for plants subjected to the closed anoxic conditions. In this treatment only $30 \%$ regrew shoots and roots, compared to $80 \%$ from the moving (constant stream of nitrogen) anoxic environment. Six days anoxia was lethal for all plants from the closed anoxic atmosphere, with only $10 \%$ survival produced from the moving anoxic environment. The latter treatment enhances survival under anoxic stress by a period of at least $24 \mathrm{~h}$.

Figures 4-5 show the dose-response effects obtained with varying concentrations of ethanol and acetaldehyde applied during a 3-d anoxic period on the subsequent development of catalase activity during the post-anoxic recovery phase. Ethanol applied during anaerobiosis resulted in increased catalase activities during anoxia, but most markedly in a post-anoxic phase. The increases noted were greater than those which occurred over the same time span when no volatile compound was added. The least concentrated ethanol treatment $\left(2.5 \mathrm{~mol} \mathrm{~m}^{-3}\right)$ did not raise catalase activity above 'control' levels. Higher concentrations each gave a further increase in catalase activity, the greatest activity measured being $1818 \mathrm{nmol} \mathrm{cm}-2 \mathrm{~min}^{-1}$ (c. 20-fold increase). A 5-fold increase in catalase 


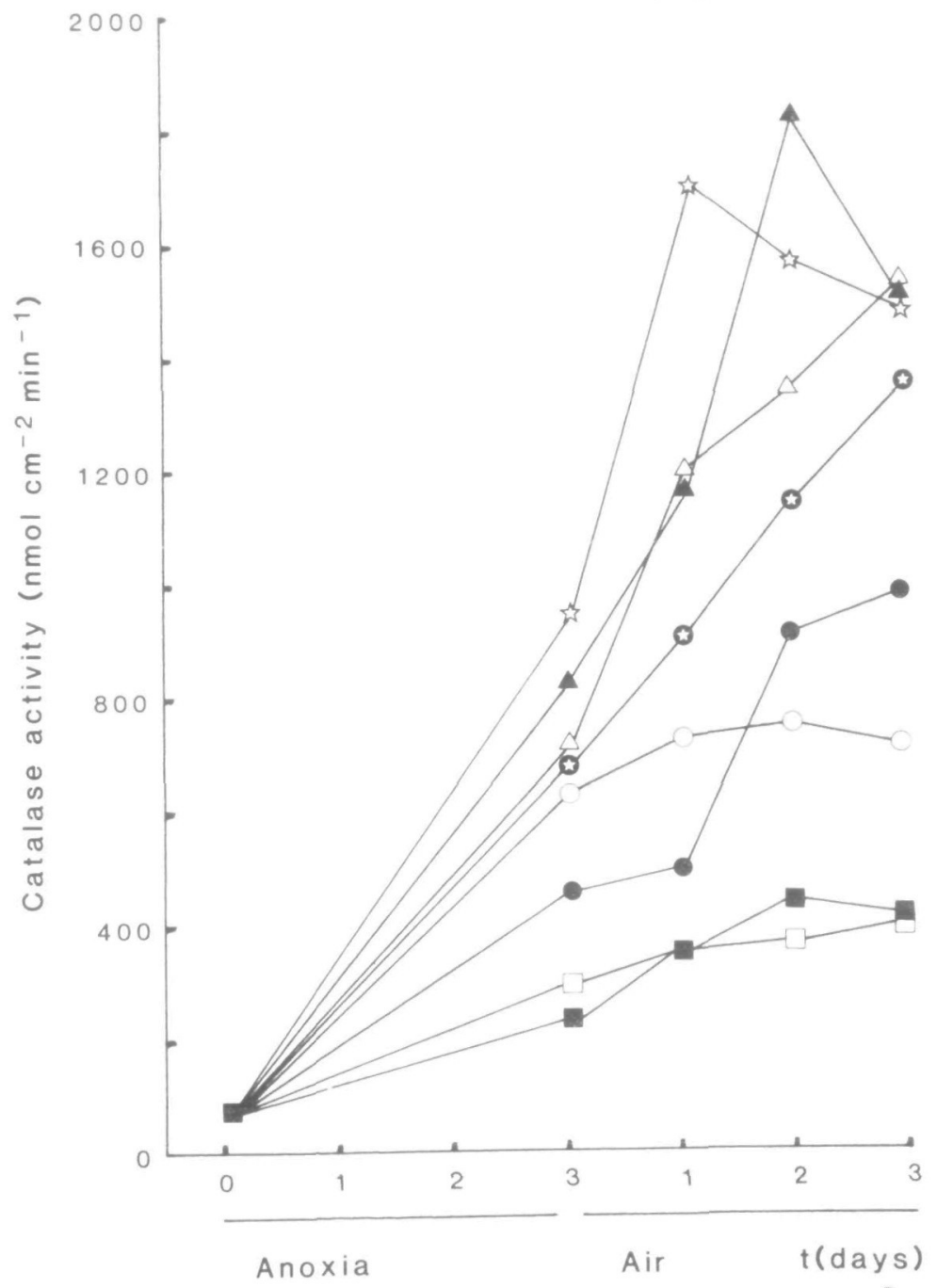

FIG. 4. The development of catalase activity on return to arr in rhizomes of Glyceria maxima, after 3 d previous anaerobic incubation with varying concentrations of ethanol added to the head space $(n=3-6)$. No ethanol applied $\left.(\square), 2.5 \mathrm{~mol} \mathrm{~m}^{-3}(\square), 10 \mathrm{~mol} \mathrm{~m}\right)^{-3}(\bullet), 50 \mathrm{~mol} \mathrm{~m}^{-3}(0), 0.1 \times 10^{3} \mathrm{~mol} \mathrm{~m}^{-3}(\Delta), 0.25 \times 10^{3} \mathrm{~mol} \mathrm{~m}^{-3}(\Delta), 0.5 \times 10^{3} \mathrm{~mol}$ $\mathrm{m}^{-3}(0), 1 \times 10^{3} \mathrm{~mol} \mathrm{~m}^{-3}(4)$. Standard error values on the final day of the experiment, indicative of values during the course of the experiment, were: $(0), \pm 154 ;(0), \pm 32 ;(\bullet), \pm 153 ;(0), \pm 81 ;(\Delta), \pm 231 ;(\Delta), \pm 173 ;(0), \pm 256$; (*), $\pm 104 \mathrm{nmol} \mathrm{cm}^{-2} \mathrm{~min}^{-1}$.

activity whether produced by incubation in a static anaerobic atmosphere or by the addition of ethanol always signalled the eventual death of the rhizomes.

Acetaldehyde also proved effective in increasing catalase activity with a marked response being found at a concentration of only $2.5 \mathrm{~mol} \mathrm{~m}^{-3}$. As with ethanol, the higher the concentration used (up to $50 \mathrm{~mol} \mathrm{~m}^{-3}$ ) the greater and more rapid the increase in catalase activity. The $0.5 \mathrm{~mol} \mathrm{~m}^{-3}$ added acetaldehyde treatment resulted in activities comparable to 'control' levels. The $0.1 \times 10^{3} \mathrm{~mol} \mathrm{\textrm {m } ^ { - 3 }}$ treatment, however, was enough to render the rhizomes moribund on return to air, with lower activities of catalase than those found in aerobic rhizomes. The highest activity measured was $1071 \mathrm{nmol} \mathrm{cm}^{-2} \min ^{-1}$ (c.12-fold compared to initial levels) in response to $2.5 \mathrm{~mol} \mathrm{~m}^{-3}$ acetaldehyde. As with the ethanol 


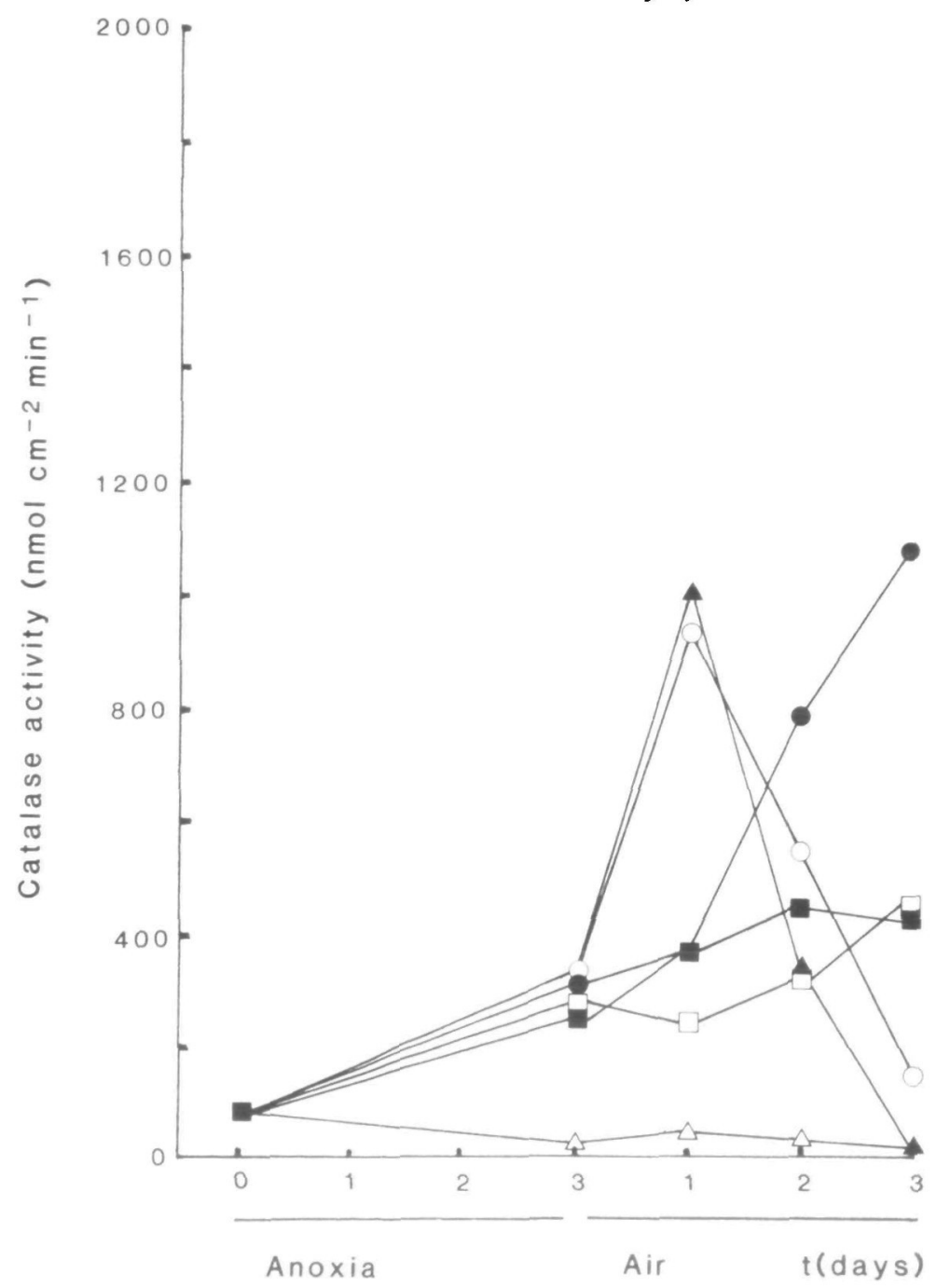

FIG. 5. The development of catalase activity on return to air in rhizomes of Glyceria maxima, after $3 \mathrm{~d}$ previous anaerobic incubation with varying concentrations of acetaldehyde added to the head space $(n=3-6)$. No acetaldehyde applied (ब), $0.5 \mathrm{~mol} \mathrm{~m} \mathrm{~m}^{-3}(\square), 2.5 \mathrm{~mol} \mathrm{~m}^{-3}(\bullet), 10 \mathrm{~mol} \mathrm{~m}^{-3}(0), 50 \mathrm{~mol} \mathrm{~m}^{-3}(\Delta), 0.1 \times 10^{3} \mathrm{~mol} \mathrm{~m}^{-3}(\Delta)$. Standard error values on the final day of the experiment, indicative of values during the course of the experiment, were: (a), $\pm 154 ;(0), \pm 188 ;(\bullet), \pm 179 ;(0), \pm 72 ;(\Delta), \pm 14 \mathrm{nmol} \mathrm{cm}^{-2} \mathrm{~min}^{-1} ;(\Delta)$, plants had perished.

experiments any acetaldehyde treatment that gave rise to catalase activities greater than $c .5$-fold the amount found under air, signalled the eventual death of the rhizome in the post-anoxic phase.

Table 2 records the ethanol and acetaldehyde concentrations and their ratio in the head space above rhizomes at the end of their anaerobic incubation and subsequently when recovering in air. Immediately before removal from anoxia the ratio of ethanol to acetaldehyde in the gas phase above incubated rhizomes stood at $86: 1\left(613 \cdot 2 \mathrm{nmol} \mathrm{g}^{-1} \mathrm{fr}\right.$. wt.: $9.5 \mathrm{nmol} \mathrm{g}^{-1}$ fr. wt.).

On removal from strict anoxia some ethanol and acetaldehyde was lost before the rhizomes were placed in the second closed system containing air, hence the obviously large 
T A B LE 2. Ethanol and acetaldehyde in the head space above G. maxima rhizomes after 4-d anoxia and during a post-anoxic phase

Mean values from 4-9 rhizomes \pm s.e.

\begin{tabular}{|c|c|c|c|}
\hline Treatment & $\begin{array}{l}\text { Ethanol } \\
\text { (nmol g }{ }^{-1} \text { fr. wt.) } \\
\text { (in gas phase) }\end{array}$ & $\begin{array}{l}\text { Acetaldehyde } \\
\text { (nmol } \mathrm{g}^{-1} \mathrm{fr} \text {. wt.) } \\
\text { (in gas phase) }\end{array}$ & $\begin{array}{l}\text { Ratio of } \\
\text { ethanol: } \\
\text { acetaldehyde }\end{array}$ \\
\hline 4-d anoxia & $613 \cdot 2 \pm 114 \cdot 0$ & $9 \cdot 5 \pm 2 \cdot 4$ & $65 \cdot 0$ \\
\hline $\begin{array}{l}\text { Vessel changed, } \\
\text { aerobic post- } \\
\text { anoxic phase } \\
+30 \mathrm{~min}\end{array}$ & $385 \cdot 7 \pm 62 \cdot 2$ & $51 \cdot 7 \pm 8 \cdot 0$ & $7 \cdot 5$ \\
\hline$+60 \mathrm{~min}$ & $381 \cdot 8 \pm 71 \cdot 2$ & $49 \cdot 8 \pm 4 \cdot 0$ & $7 \cdot 7$ \\
\hline$+120 \mathrm{~min}$ & $356.4 \pm 16.1$ & $69 \cdot 6 \pm 12 \cdot 3$ & $5 \cdot 1$ \\
\hline$+240 \mathrm{~min}$ & $313.9 \pm 27.3$ & $66.4 \pm 8.2$ & 4.7 \\
\hline$+360 \mathrm{~min}$ & $327.8 \pm 28.5$ & $67 \cdot 3 \pm 4 \cdot 8$ & 4.9 \\
\hline
\end{tabular}

fall in ethanol concentration at this stage. Thirty minutes after restoration of the oxygen supply the ratio was found to be $7.5: 1\left(385.7 \mathrm{nmol}^{-1} \mathrm{fr}\right.$. wt.:51.7 $\mathrm{nmol}^{-1} \mathrm{fr}$. wt.). Thereafter a further, though less significant, change in ratio took place to $4.9: 1$ by $6 \mathrm{~h}$ of the post-anoxic phase. It appears that as soon as the rhizomes are returned to air, ethanol is oxidized at a rapid rate, and during the first minutes and hours of recovery from the anoxic stress, acetaldehyde is accumulated as the first step in the metabolism of ethanol.

\section{DISCUSSION}

The three anoxia-intolerant species in this investigation showed similar responses to anoxic stress. Large increases in catalase activity occurred in a 3-d aerobic recovery phase after each period of anaerobic treatment. On the basis of the effects obtained by experimentally removing ethanol (open anaerobic environment) and adding ethanol (exposure to ethanol vapour) we suggest that in these plants catalase may be involved in the post-anoxic oxidation of ethanol accumulated during anaerobiosis. The consequence of a catalase-mediated oxidation of ethanol in the post-anoxic phase will be to produce a higher concentration of acetaldehyde than that which might be achieved due solely to alcohol dehydrogenase activity. The surge in acetaldehyde content observed in post-anoxic tissues that have accumulated ethanol may contribute, therefore, to the post-anoxic death of the tissues. The experiments in which acetaldehyde was added to the anaerobic atmosphere demonstrated the high toxicity of this substance at low concentrations. In experiments on rat liver Oshino, Jamieson, Sugano, and Chance (1975) reported that the contribution of catalase to the oxidation of ethanol was $c .10 \%$ in endogenous conditions, and rose to $30 \%$ or more when the rate of hydrogen peroxide generation was increased. Alcohol dehydrogenase then catalysed the remaining proportion of the reaction.

The 'catalase' and 'peroxidase' modes of catalase activity were examined in an earlier study (Oshino et al., 1973) and described thus:

$$
\begin{gathered}
\text { catalase }+\mathrm{H}_{2} \mathrm{O}_{2} \bumpeq \text { catalase- } \mathrm{H}_{2} \mathrm{O}_{2} \text { (compound I) } \\
\text { catalase- } \mathrm{H}_{2} \mathrm{O}_{2}+\mathrm{H}_{2} \mathrm{O}_{2} \bumpeq \text { catalase }+2 \mathrm{H}_{2} \mathrm{O}+2 \mathrm{O}_{2} \\
\text { catalase- } \mathrm{H}_{2} \mathrm{O}_{2}+\mathrm{CH}_{3} \mathrm{CH}_{2} \mathrm{OH} \rightarrow \text { catalase }+2 \mathrm{H}_{2} \mathrm{O}+\mathrm{CH}_{3} \mathrm{CHO} \text {. }
\end{gathered}
$$


The second molecule of peroxide functions as a hydrogen donor in the catalase reaction, whereas ethanol takes this role in the peroxidatic reaction. In conditions of excess ethanol in plants, such as after a period of anaerobiosis, oxidation of this fermentation product to acetaldehyde could be accomplished not only by ADH but also by catalase provided there is a slow but continuous peroxidase generation source (Donaldson et al., 1985).

The ability to oxidize ethanol aerobically has been demonstrated in a wide variety of plants and plant tissues (Cossins, 1978). In the latter investigations ADH was considered as the principal catalyst for the first step in ethanol metabolism even although the involvement of catalase in mammals was already well-known (Lieber, 1975). Our experiments with applications of ethanol to the anoxic head space, which produced significant increases in catalase during recovery from anoxia (Fig. 4) suggest the involvement of this enzyme in ethanol oxidation in plants. Equally, the removal of ethanol by the use of a circulating anaerobic atmosphere (Fig. 3) reduces the post-anoxic activity of catalase. The kinetics of the reverse reaction mediated by $\mathrm{ADH}$ above are unlikely to achieve the increase in acetaldehyde concentration relative to ethanol that takes place so quickly on re-exposure to air. In the experiments with the open versus closed atmospheres, where the former treatment very effectively removes volatile substances from the rhizome tissue, our plants showed a direct relationship between ethanol accumulation and catalase activity.

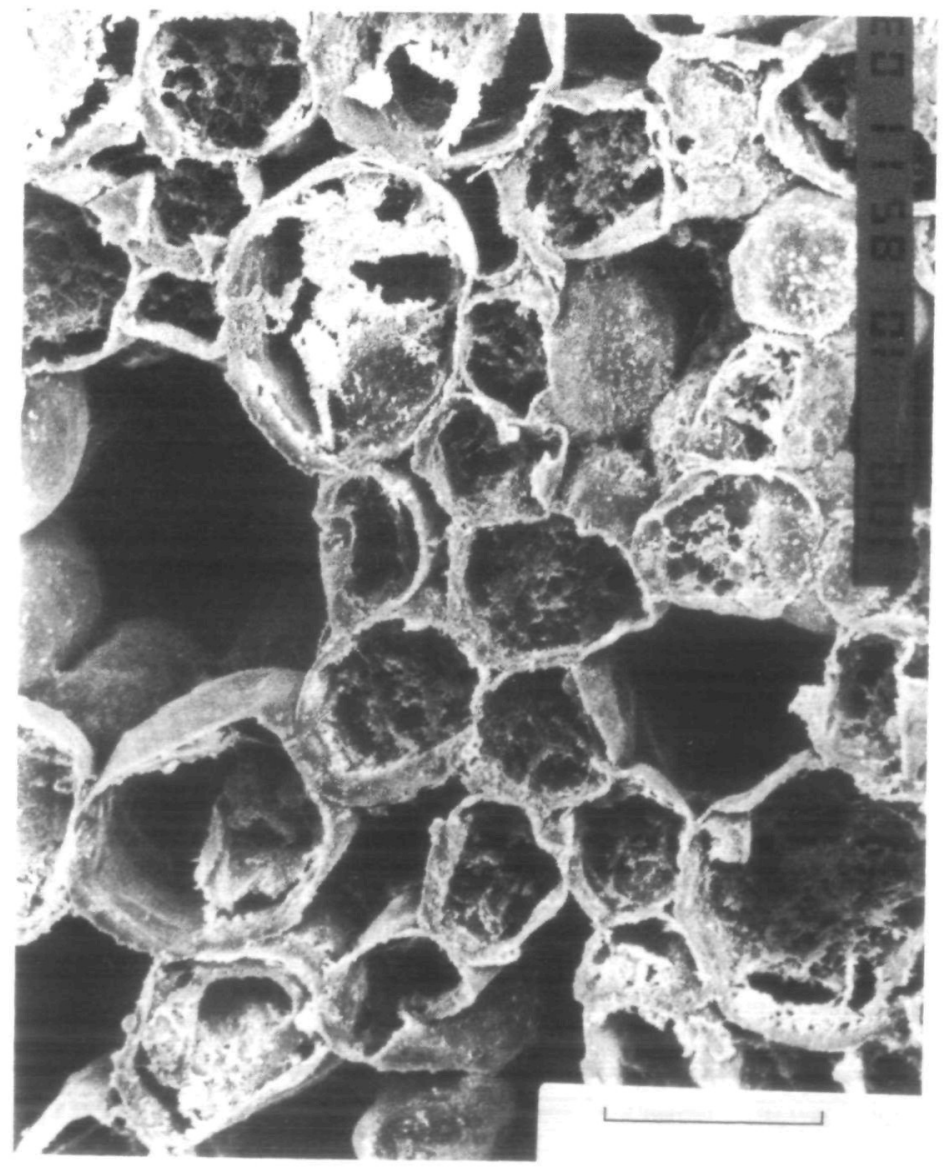

PLATE 1. Scanning electron micrograph of transverse section of the cortex of a rhizome of Iris pseudacorus showing development of large air spaces (aerenchyma). Scale $=100 \mu \mathrm{m}$. 
The surge in acetaldehyde production seen in G. maxima on return to air (Table 2) may be harmful to the plant (Fig. 6) and instrumental in causing cell death during the post-anoxic phase, since the hydrated aldehyde produces cross-linkages in proteins (Schauenstein, Esterbauer, and Zollner, 1977). Free acetaldehyde also reacts with amino groups of amino acids and primary amines to give carbinolamines and Schiff's bases. If acetaldehyde is present in significant amounts, such reactions will profoundly affect energy metabolism within the cell. Other workers (Cossins and Turner, 1963; Effer and Ranson, 1967) have also noted temporary increases in acetaldehyde during ethanol metabolism. Regulation of ethanol oxidation, especially when excess amounts of this fermentation product are present, may then be a determining factor in anoxia tolerance. Tissue death under anoxia was noted in this study to take place more rapidly when acetaldehyde was added in the vapour phase to the anaerobic environment. The apparent increase in catalase activity in response to acetaldehyde applied to the head space is probably due to the fact that during anoxia the rhizomes will convert acetaldehyde to ethanol by means of $\mathrm{ADH}$, and this endogenously produced ethanol would induce catalase in the same manner as in the ethanol treatment experiments.

In the anoxia sensitive species examined, I. germanica, collapse of the tissue is again seen

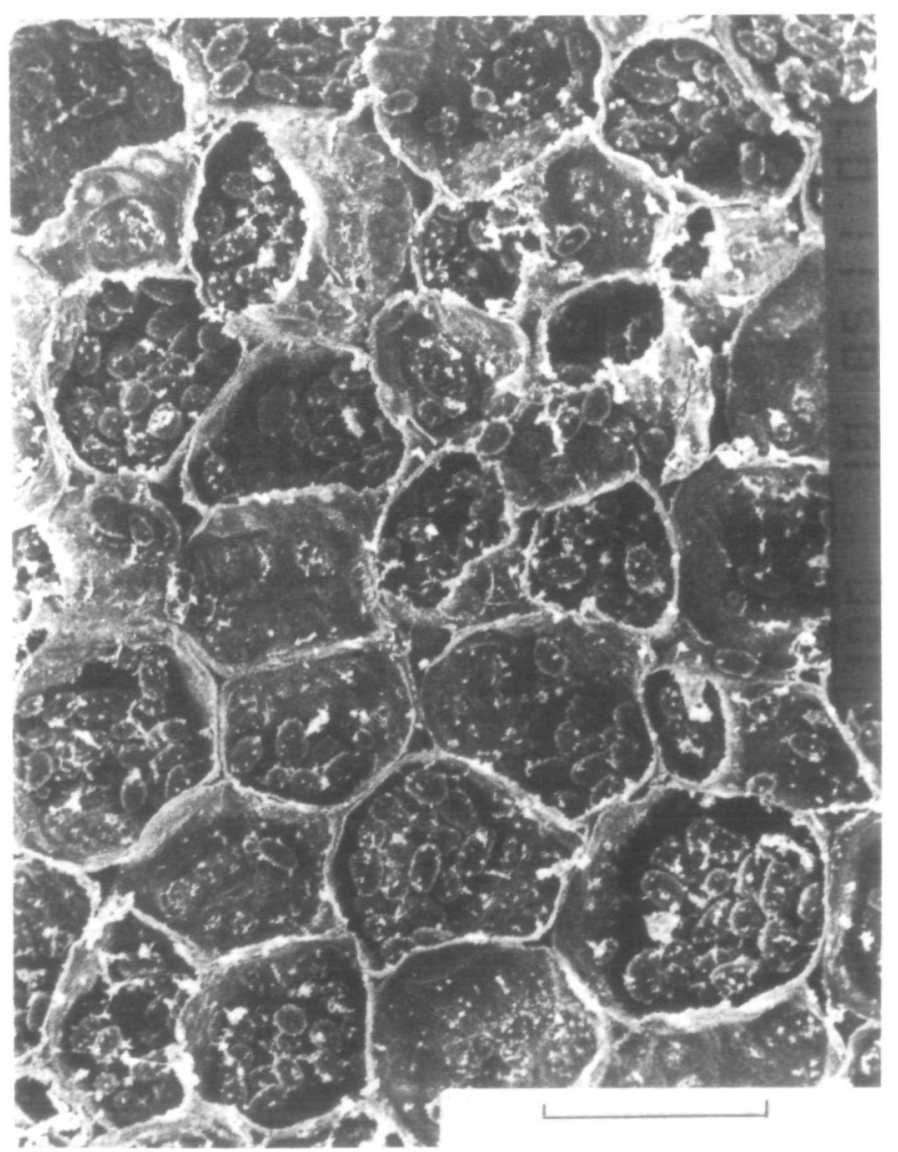

Plate 2. Scanning electron micrograph of transverse section of the cortex of a rhizome of Iris germanica showing dense tissue lacking air spaces (aerenchyma). Scale $=100 \mu \mathrm{m}$. 
in the post-anoxic phase, the rhizomes surviving the actual period of anoxic stress. Rhizome tissue of this plant is made up of particularly densely packed cells, compared with its relative I. pseudacorus, where there are plentiful air spaces, especially in the cortex (Plates 1 and 2). The large air spaces found in the roots and rhizomes of some flood-tolerant species are usually considered as playing a role in the downward diffusion of oxygen (Armstrong, 1979). In addition to this role the possession of large air spaces will also serve to ventilate cells which accumulate volatile products of glycolysis. The larger the air space the fewer living cells per unit volume that will generate toxins and the greater the facility provided for their anaerobic ventilation. In many tissues the extent of air space production is so great that its functional significance for the downward diffusion of oxygen has been questioned (Williams and Barber, 1961). Whether or not the amount of air space available can exceed the need for oxygen provision to submerged organs is, however, still not clear. By contrast the benefit of large air spaces in facilitating the dilution of volatile anaerobic products is readily apparent. The observation that moving anaerobic environments can prolong anaerobic life in chickpea seedlings (Crawford and Zochowski, 1984) indicates the benefit of anaerobic ventilation alone without any supply of oxygen. According to Bown (1985), in a bulky organ where there is a lengthy diffusion pathway, carbon dioxide will accumulate and in concentrations of $5 \%$ or more may lower intracellular $\mathrm{pH}$. If this does occur, but is not sufficient to render the tissue moribund, it is possible that there may be some intracellular damage, e.g. free iron in the ferrous form may be available and on return to air may catalyse any of the following reactions involving oxygen radicals:

$$
\begin{gathered}
\mathrm{Fe}^{2+}+\mathrm{O}_{2} \longrightarrow \mathrm{Fe}^{3+}+\mathrm{O}_{2^{-}} \\
\text {Superoxide dismutase } \\
\mathrm{O}_{2}^{-}+\mathrm{O}_{2}^{-}+2 \mathrm{H}^{+} \longrightarrow \mathrm{H}_{2} \mathrm{O}_{2}+\mathrm{O}_{2}
\end{gathered}
$$

(Hendry and Brocklebank, 1985)

$$
\mathrm{Fe}^{2+}+\mathrm{H}_{2} \mathrm{O}_{2} \longrightarrow \mathrm{Fe}^{3+}+\mathrm{OH}^{\cdot}+\mathrm{OH}^{-} \quad \text { (Fenton reaction). }
$$

Traces of $\mathrm{Fe}^{3+}$ can react further with peroxide:

$$
\mathrm{Fe}^{3+}+\mathrm{H}_{2} \mathrm{O}_{2} \longrightarrow \mathrm{Fe}^{2+}+\mathrm{O}_{2}^{-}+\mathrm{H}^{+}
$$

(Halliwell and Gutteridge, 1984)

$$
\mathrm{O}_{2}^{-}+\mathrm{H}_{2} \mathrm{O}_{2} \underset{\text { catalyst }}{\stackrel{\mathrm{Fe} \text { salt }}{\longrightarrow}} \mathrm{O}_{2}+\mathrm{OH}^{-}+\mathrm{OH}^{-}
$$

(Halliwell and Gutteridge, 1985).

A significant increase in oxygen uptake has been shown in Iris germanica rhizomes that had undergone $8 \mathrm{~d}$ anoxia, when oxygen supply was restored (Monk et al. 1984). It is possible here that oxygen radicals were being formed (Fig. 6), and that some lipid peroxidation was taking place. It would be useful to know whether free radical scavengers, such as glutathione, ascorbate and -tocopherol are as active after a period of oxygen deprivation as under air in this species.

I. germanica is a dryland plant, probably originating from the Mediterranean region, and may, in flooded conditions, show an enhanced uptake of iron which might affect the plant deleteriously in the manner outlined above, as suggested by Hendry and Brocklebank (1985). In our experimental conditions this danger is excluded, but if some intracellular damage does occur, ferrous iron might be present and start off reactions which result in the generation of significant amounts of hydrogen peroxide. With catalase enzyme in sufficient supply a catalase-ethanol oxidation reaction could take place, where localized production of 


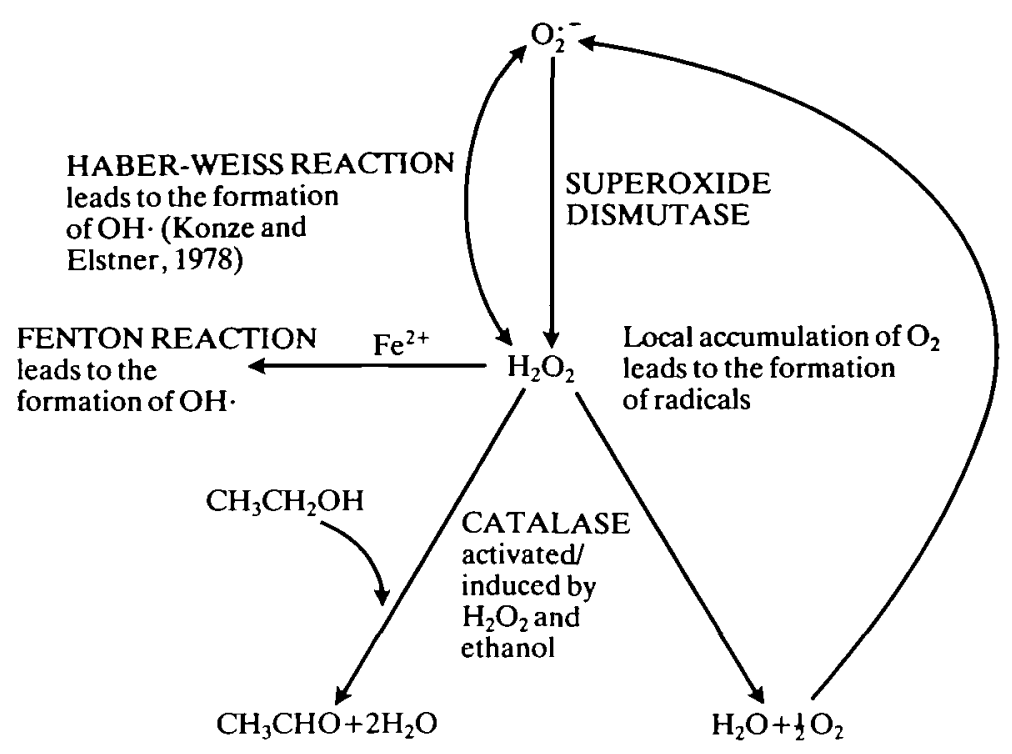

Fig. 6. Scheme of suggested events leading to post-anoxic injury. Provided there is significant hydrogen peroxide generation, ethanol is converted by catalase (in an alternative reaction to that catalysed by ADH) to acetaldehyde, which is extremely harmful to the cell if accumulated. Other reactions between oxygen radicals may form hydroxyl radicals which cause indiscriminate intracellular damage, since they have extremely high reaction rate constants for almost every type of molecule found in living cells.

oxygen might give rise to further oxygen radical formation and activation of more catalase (Fig. 6).

Oshino et al. (1975) have also suggested that on the appearance of significant quantities of acetaldehyde, aldehyde oxidase might provide a source of peroxide for the catalase-ethanol oxidation. Acetaldehyde itself probably also contributes to cell damage and may help escalate the deleterious reactions.

In contrast to the anoxia-intolerant species, large amounts of ethanol are not found in the storage organs of the anoxia tolerant $A$. calamus, I. pseudacorus and $S$. lacustris (Monk et al., 1984). Excessive accumulation may be avoided since the volatile product readily diffuses into air spaces found in the rhizomes of these species (Plate 1), and thence into the surrounding environment. Therefore, on return to air any oxidation of ethanol to acetaldehyde will be relatively small. There are no high catalase activities, so that additional oxidation by this means probably does not occur.

In conclusion, attention is drawn to the inter-relationship between post-anoxic metabolic events and the precise nature of the treatment of the tissues during anaerobiosis. Anoxic tissue-ventilation which reduces the accumulation of the volatile products of anaerobiosis without alleviating the anoxic stress can have a direct bearing on the metabolism and survival of tissues during the post-anoxic phase. There is clearly, therefore, a need to consider both anoxic and post-anoxic events in any study of the sensitivity of plants to low oxygen stress.

\section{ACKNOWLEDGEMENTS}

We thank Dr M. I. S. Hunter for helpful discussion. This research was supported by a grant from the Natural Environment Research Council which is gratefully acknowledged. 


\section{LITERATURE CITED}

ARMSTRONG, W., 1979. Aeration in higher plants. Advances in Botanical Research, 7, 225-332.

BARCLAY, A. M., and CRAWFORD, R. M. M., 1982. Plant growth and survival under strict anaerobiosis. Journal of Experimental Botany, 33, 541-9.

Bown, A. W., 1985. $\mathrm{CO}_{2}$ and intracellular pH. Plant, Cell and Environment, 8, 459-65.

Cossins, E. A., 1978. Ethanol metabolism in plants. In Plant life in anaerobic environments. Eds. D. D. Hook and R. M. M. Crawford. Ann Arbor, Michigan. Pp. 169-202.

- and TURNER, E. R., 1963. The metabolism of ethanol in germinating pea seedlings. Journal of Experimental Botany, 8, 290-8.

Crawford, R. M. M., and Zochowski, Z. M., 1984. Tolerance of anoxia and ethanol toxicity in chickpea seedlings (Cicer arietinum L.). Ibid. 35, 1472-80.

Donaldson, R. P., Soochan, P., and Zaras, A., 1985. Anaerobic stress in germinating castor bean, ethanol metabolism, and effects on subcellular organelles. Plant Physiology, 77, 978-83.

EFFER, W. R., and RANSON, S. L., 1967. Respiratory metabolism in buckwheat seedlings. Ibid. 42, 1042-52.

EPSTEIN, E., 1972. Mineral nutrition of plants: principles and perspectives. John Wiley and Sons, Inc.

Felder, M. R., SCANDalios, J. G., and LiU, E. H., 1973. Purification and partial characterization of two genetically defined alcohol dehydrogenase isozymes in maize. Biochimica et biophysica acta, 317, 149-59.

Flohe, L., LOSCHEN, G., GuENZLER, W. A., and EiCHele, 1972. Glutathione peroxidase. V. The kinetic mechanism. Hoppe-Seyler's Zeitschrift für Physiologische Chemie, 353, 789-99.

Halliwell, B., 1974. Oxidation of formate by peroxisomes and mitochondria from spinach leaves. Biochemical Journal, 138, 77-85.

- and GUTTERIDGE, J. M. C., 1984. Oxygen toxicity, oxygen radicals, transition metals and disease. Ibid. 219, 1-14.

- 1985. Free radicals in biology and medicine. Oxford Press.

HENDRY, G. A. F., and BRoCKLEBANK, K. J., 1985. Iron-induced oxygen radical metabolism in waterlogged plants. New Phytologist, 101, 199-206.

Hetherington, A. M., Hunter, M. I. S., and Crawford, R. M. M., 1983. Survival of Iris species under anoxic conditions. Annals of Botany, 51, 131-3.

KONZE, J. R., and ELSTNER, E. F., 1978. Ethane and ethylene formation by mitochondria as indication of aerobic lipid degradation in response to wounding plant tissue. Biochimica et biophysica acta, $528,213-21$.

LIEBER, C. S., 1975. Interference of ethanol in hepatic cellular metabolism. Annals New York Academy of Sciences, 252, 24-50.

Monk, L. S., Crawford, R. M. M., and Braendle, R., 1984. Fermentation rates and ethanol accumulation in relation to flooding tolerance in rhizomes of monocotyledonous species. Journal of Experimental Botany, 35, 738-45.

Oshino, N., Jamieson, D., Sugano, T., and Chance, B., 1975. Optical measurement of the catalase-hydrogen peroxide intermediate (compound I) in the liver of anaesthetized rats and its implication to hydrogen peroxide production in situ. Biochemical Journal, 146, 67-77.

- Oshina, R., and CHANCE, B., 1973. The characteristics of the 'peroxidatic' reaction of catalase in ethanol oxidation. Ibid. 131, 555-67.

Rober TS, J. K. M., Callis, J., Jardetzky, O., Walbot, V., and Freeling, M., 1984. Cytoplasmic acidosis as a determinant of flooding intolerance in plants. Proceedings National Academy of Sciences, 81, 6029-33.

SChauenstein, E., Esterbauer, H., and Zollner, H., 1977. Aldehydes in biological systems. Their natural occurrence and biological activities. Pion Ltd.

Sorenson, J. C., and Scandalios, J. G., 1976. Developmental expression of a catalase inhibitor in maize. Plant Physiology, 57, 351-2.

TOlBerT, N. E., 1981. Metabolic pathways in peroxisomes and glyoxysomes. Annual Review of Biochemistry, 50, 133-57.

VIGIL, E. L., 1973. Structure and function in plant microbodies. Sub-Cellular Biochemistry, 2, 237-85.

Willaams, W. T., and BARBer, D. A., 1961. The functional significance of aerenchyma in plants. Symposium of the Society for Experimental Biology, 15, 132-54. 